\title{
NORMAL GROWTH AND PERSISTENCE OF CORPORA LUTEA OF BOTH OVARIES IN THE UNILATERALLY PREGNANT GUINEA-PIG
}

\author{
RUTH DEANESLY \\ A.R.C. Institute of Animal Physiology, Babraham, Cambridge
}

(Received 18th August 1967)

Guinea-pigs were from the colony at the Institute. Examination of the animals and operative and histological techniques were the same as in previous work (Deanesly, 1967).

In the first group (Table 1, Group 1), one uterine horn was removed from four females; one of these failed to mate and another had no corpora lutea on the side of the sterile horn. Such animals are omitted from Table 1. For Group 2, a small piece of one Fallopian tube was removed without disturbance of the vascularization of the uterus or ovary, and for Group 3 one uterine horn was severed or ligatured near the middle. Ovaries were sectioned serially at $7 \mu$ after fixation in Bouin's fluid, and one in six sections were mounted. Two diameters at right angles were measured $(\times 27)$ across the largest sections of each corpus luteum and a third measurement was obtained by counting the number of sections on which it appeared. From these a mean diameter was calculated. Owing to the irregular shapes of many corpora lutea, these mean diameters, like the spherical estimates obtained from the same measurements by other workers, are necessarily only accurate within limits as indicators of total volume. Minor size differences cannot therefore be regarded as significant except in association with consistent histological differences.

Sections through corpora lutea of unilateral pregnancy have been examined over several years and no obvious differential regression was observed. Recent work on the subject, and discussion of uterine luteolytic effects both in the guinea-pig (Oxenreider \& Day, 1967) and in the pig (which also shows cycle prolongation after hysterectomy), has made it desirable to supplement the older material and to publish the findings.

In the normal guinea-pig, enlargement of the corpora lutea from cyclic to pregnancy size occurs between Days 15 and 21, and thereafter the size is maintained until near the end of the 68th day of pregnancy, though with some shrinkage and variability from about Day 55 (Rowlands, 1956).

Table 1 summarizes the experimental results. The mean diameters of the corpora lutea, allowing for some regression at 56 days, are all within the normal range, except for one $(1.39 \mathrm{~mm})$ on the pregnancy side. In one of the two intact animals the ovary on the sterile side was unusually small and the luteal 
cells were less developed than those on the other side, but the corpus luteum was not regressing. All other corpora lutea were histologically similar in left and right ovaries; in particular it was noted that mitotic figures in luteal cells, which are normally present during the 4th week of pregnancy, were equally abundant on the two sides, an indication that corpus luteum growth was proceeding normally. The average mean diameters in Groups 2 and 3, excluding corpora lutea at 56 days, are almost identical on the sterile and pregnant sides $(1.91,1.92 \mathrm{~mm}$ and $1.80,1.81 \mathrm{~mm})$.

TABLE 1

DIAMETERS OF GORPORA LUTEA IN UNILATERAL PREGNANGY

\begin{tabular}{|c|c|c|c|c|}
\hline \multirow{2}{*}{$\begin{array}{c}\text { Type of } \\
\text { pregnancy }\end{array}$} & \multirow{2}{*}{$\begin{array}{c}\text { Days of } \\
\text { pregnancy }\end{array}$} & \multicolumn{2}{|c|}{ Mean diameters $(\mathrm{mm})$} & \multirow{2}{*}{$\begin{array}{l}\text { No. of } \\
\text { embryos }\end{array}$} \\
\hline & & $A^{*}$ & $B \dagger$ & \\
\hline Intact & $\begin{array}{l}21 \\
21\end{array}$ & $\begin{array}{l}1.62 \\
1.67\end{array}$ & $\begin{array}{l}1 \cdot 79,1 \cdot 76,1 \cdot 78 \\
\text { Large, sections } \\
\text { irregular (3) }\end{array}$ & $\begin{array}{l}3 \\
3\end{array}$ \\
\hline Group 1 & $\begin{array}{l}21 \\
46\end{array}$ & $\begin{array}{l}1.73,1.75 \\
1.83\end{array}$ & $\begin{array}{l}1 \cdot 39 \\
1 \cdot 80,1 \cdot 86\end{array}$ & $\begin{array}{l}1 \\
2\end{array}$ \\
\hline Group 2 & $\begin{array}{l}21 \\
23 \\
27 \\
29 \\
42 \\
56\end{array}$ & $\begin{array}{l}1.93,2.06 \\
1 \cdot 75 \\
1 \cdot 72,1.68 \\
2 \cdot 00 \\
2 \cdot 22 \\
1 \cdot 55,1.55\end{array}$ & $\begin{array}{l}2 \cdot 00,1 \cdot 85 \\
1 \cdot 78,1 \cdot 77 \\
1 \cdot 80 \\
1 \cdot 73,1 \cdot 86,1 \cdot 85 \\
2 \cdot 10,2 \cdot 13,2 \cdot 19 \\
1 \cdot 81,1 \cdot 53,1 \cdot 58\end{array}$ & $\begin{array}{l}2 \\
2 \\
1 \\
3 \\
3 \\
3\end{array}$ \\
\hline Group 3 & $\begin{array}{l}24 \\
28 \\
33 \\
39\end{array}$ & $\begin{array}{l}1.89,1.74 \\
1.81,1.79 \\
1.84 \\
1.73\end{array}$ & $\begin{array}{l}1.66,1.71,1.74,1.87 \\
1.82,1.86 \\
1.94,1.74,1.92 \\
1 \cdot 78,1.85\end{array}$ & $\begin{array}{l}4 \\
2 \\
3 \\
2\end{array}$ \\
\hline
\end{tabular}

* A: Corpora lutea corresponding to sterile horn.

$\dagger \mathrm{B}$ : Corpora lutea corresponding to pregnant horn.

Mean diameters of other corpora lutea at similar stages of normal pregnancy were as follows: 16 days, $1.97 \mathrm{~mm} ; 20$ to 21 days, 1.72 to 2.11 $\mathrm{mm} ; 23$ to 28 days, 1.74 to $1.92 \mathrm{~mm}$.

These findings are in clear contradiction to the conclusions of Oxenreider \& Day, although the operative treatment of their Groups 2 and 3 was similar to the comparable groups in the present work. These authors found some corpora lutea of full size on both sides up to the 40th day of pregnancy, but they state, after a series of inconsistent results: "Corpora lutea of unilaterally pregnant guinea-pigs regressed in the ovary adjacent to a non-gravid uterine horn while luteal maintenance occurred in the opposite ovary adjacent to a gravid horn". After unilateral hysterectomy, however, they did not find differential corpus luteum regression.

The essential factor controlling the maintenance of pregnancy corpora lutea in the guinea-pig is the functional placenta. If the placenta is removed, leaving the uterus in position, then 4 days later the corpora lutea are regressed (Klein, 1939).

Corpora lutea shrink when pregnancy is terminated or disturbed, as, for instance, when one of two implantations has regressed and the other is likely to follow. A placental luteotrophic stimulus, inadequate for full luteal maintenance, may on occasion lead to differential regression of corpora lutea of the 
same group in pregnant guinea-pigs, like that observed in hypophysectomized, non-pregnant ones (Heap, Perry \& Rowlands, 1967). It is noticeable that the twelve females in Oxenreider \& Day's Group 2 had an average of only 1.7 foetuses and this may perhaps explain some of their reduced corpora lutea. If differential regression does occur late in pregnancy, it cannot be used as evidence of a uterine luteolytic factor derived from the sterile horn.

No regression of corpora lutea on the side of the sterile horn was found after detailed examination of both ovaries in the 21 to 56 days unilaterally pregnant guinea-pigs of the present series. The luteotrophic action of the placenta is presumably systemic.

The author acknowledges with thanks a grant from the Medical Research Council.

\section{REFERENCES}

DeAnesly, R. (1967) The role of the fertilized egg: reactions in the guinea-pig uterus at ovo-implantation and after thread traumatization. 7. Reprod. Fert. 14, 243.

Heap, R. B., Perry, J. S. \& Rowlands, I. W. (1967) Corpus luteum function in the guinea-pig: arterial and luteal progesterone levels, and the effects of hysterectomy and hypophysectomy. F. Reprod. Fert. 13, 537 .

KLeIN, M. (1939) Action du placenta sur le corps jaune gravidique et sur le cycle vaginal chez le cobaye. C. r. Séanc. Soc. Biol. 130, 1393.

OXENREIDER, S. L. \& DAY, B. N. (1967) Regression of corpora lutea in unilaterally pregnant guineapigs. 7. Endocr. 38, 279.

Rowlands, I. W. (1956) The corpus luteum of the guinea-pig. Ciba Foundation Coll. Ageing, 2, 69. 